\title{
Wpływ osadnictwa olęderskiego na morfologię nadwiślańskich obszarów zalewowych - na przykładzie Kępy Kiełpińskiej
}

\author{
Olęder settlement impact on morphology of the Vistula river floodplain. Kępa Kiełpińska \\ case study
}

\author{
Urszula Zawadzka-Pawlewska*, Irena Tsermegas \\ Uniwersytet Warszawski, Zakład Geomorfologii; *urszula.zawadzka@uw.edu.pl
}

\begin{abstract}
Zarys treści: W rejonie Warszawy i w samej stolicy występuje wiele śladów osadnictwa olęderskiego. Tekst prezentuje wyniki pilotażowych badań nad wpływem tej kolonizacji na ukształtowanie rzeźby Kępy Kiełpińskiej, zagospodarowanej na początku XIX w. Bezpośrednie skutki antropopresji określono na podstawie porównania archiwalnych map topograficznych z lat: 1783, 1794, 1843, 1914-1915, 1936 oraz mapy współczesnej. W oparciu o dwa wiercenia porównano cechy litologiczne (uziarnienie i zawartość materii organicznej) podłoża po dwóch stronach olęderskiej grobli. Wykazano, że w pierwszej fazie modyfikacja rzeźby polegała na utworzeniu nowych form - grobli, rowów, nasypów, które są do dziś wyraźnie widoczne $\mathrm{w}$ terenie. $\mathrm{W}$ późniejszych etapach wpłynęło to na cechy gruntów użytkowanych rolniczo - groble i pasy zarośli wierzbowo-topolowych oraz płotki z wikliny zatrzymywały grubszy materiał, a na ich zapleczu osadzały się drobniejsze frakcje, wzbogacone w materię organiczna, transportowane w zawiesinie. Uzyskane wyniki uzasadniają potrzebę dalszych badań nad morfologicznymi skutkami osadnictwa olęderskiego w rejonie Warszawy.
\end{abstract}

Słowa kluczowe: Kępa Kiełpińska, olędrzy, antropopresja, terasa zalewowa Wisły

\begin{abstract}
In Warsaw and its vicinity, many signs of the Olęder settlement are present. Paper presents the results of the pilot study on the Olęder settlement impact on the relief of the Kępa Kiełpińska, which was brought into cultivation in the beginning of the XIX century. Direct results of the human impact were specified on basis of the archival and modern topographic maps. On basis of two drills the lithology features of the ground on both sides of the Olęder causeway were compared (grain size distribution and LOI). In the first phase, relief modification consisted of the creation of new forms - causeways, trenches, embankments, which are still visible in landscape. In later phases, above mentioned modifications, had impact on features of the land used for agriculture - causeways and osier fences and belts composed from poplar and willow were stopping more coarse material, and on their back, more fine, enriched in organic matter, material transported in suspension was deposited. Obtained results justify the need of the future research on the impact of the Olęder settlement in the vicinity of Warsaw.
\end{abstract}

Key words: Kępa Kiełpińska, Olęders, human impact, floodplain of Vistula river

\section{Wstęp}

Doliny rzeczne to obszary szczególnie wrażliwe na antropopresję. Działalność człowieka znajduje w ich rzeźbie wyraz zarówno bezpośredni, jak i pośredni (Goudie 2006). Tereny nisko położone w sąsiedztwie koryt dużych rzek, szczególnie w szerokich dnach pradolin, stanowiły w przeszłości i do dziś stanowią wyzwanie dla osadnictwa (Kobojek, Kobojek 2013). Ich zagospodarowanie wymagało regulacji stosunków wodnych, co przyczyniało się do znacznych zmian w krajobrazie, w tym do zmian litologii utwo- rów powierzchniowych i modyfikacji rzeźby równiny zalewowej. Formy gospodarowania w dnie doliny, jedne $z$ ciekawszych na obszarze Polski, a stosunkowo słabo zbadane pod względem skutków morfologicznych, wiążą się z tzw. osadnictwem olęderskim. Zagadnienie to $\mathrm{w}$ ograniczonym zakresie poruszane było głównie w pracach dotyczących Żuław Wiślanych (Plit 2010) i dorzecza Warty (Forysiak 2005, Forysiak i in. 2007). Liczne ślady funkcjonowania olędrów można znaleźć także $\mathrm{w}$ dolinie Wisły na terenie Warszawy i w jej bezpośrednim sąsiedztwie, ale ich aspekt geomorfologiczny nie stał się jak dotąd 
przedmiotem żadnego szczegółowego opracowania naukowego. Skutki obecności olędrów na tym terenie były w ostatnich latach przedmiotem badań krajobrazowych (Myga-Piątek 2013, Plit 2016).

Natomiast autorki niniejszej publikacji przeprowadziły pilotażowe badania zmierzające do wykazania znaczącej roli antropopresji w ukształtowaniu współczesnej rzeźby jednej $\mathrm{z}$ typowych mazowieckich kęp wiślanych - Kępy Kiełpińskiej.

\section{Morfologia doliny Wisły na północ od Warszawy}

Dolina Wisły na odcinku warszawskim jest wyraźnie asymetryczna. Od zachodu ogranicza ją wysoczyzna morenowa Równiny Warszawskiej, dlatego w obrębie centralnych dzielnic miasta lewobrzeżna równina zalewowa, miejscami dwudzielna, znacznie się zwęża, brak wyższych, vistuliańskich teras nadzalewowych (odpowiadających poziomom otwockiemu i falenickiemu), a terasa nadzalewowa niższa (praska) ma ograniczony zasięg i miejscami całkowicie zanika. Prawobrzeżna równina zalewowa ma podobną szerokość jak na zachodzie (na obu brzegach to około 1-1,5 km), ale powyżej niej występują szerokie terasy nadzalewowe (Sarnacka 1980). Wkraczając na teren północnych dzielnic miasta (Bielany i Białołęka), do- lina rozszerza się i uchodzi do Kotliny Warszawskiej. Koryto Wisły na tym odcinku wykazuje tendencję do roztokowania (Starkel 2001).

Zgodnie $z$ definicjami zamieszczonymi w ,Słowniku języka polskiego" (Doroszewski 1969), słowo „kępa” oznacza „skupisko drzew, krzewów, kwiatów itp., małą wyniosłość $\mathrm{w}$ terenie, zwłaszcza bagnistym” albo „wyspę na rzece lub jeziorze porosłą krzewami i drzewami”. Kępa Kiełpińska to osiedle w gminie Łomianki, położone $\mathrm{w}$ pobliżu miejscowości Kiełpin, obejmujące fragment dna doliny Wisły objęty przez pierwsze zakole tej rzeki poniżej Warszawy. Zasięg dawnej wyspy-kępy wyznaczają: od północnego wschodu obecne koryto Wisły, a od południowego zachodu ciąg starorzeczy z jeziorami: Fabrycznym, Kiełpińskim i Dziekanowskim. Ze względu na niskie położenie obszar ten jest narażony na występowanie powodzi (ryc. 1). Szerokość lewobrzeżnej równiny zalewowej osiąga tu maksymalnie $2,5 \mathrm{~km}$. Budują ją piaski przewarstwione madami. Około $2-3 \mathrm{~m}$ powyżej rozciąga się niska terasa nadzalewowa, pradolinny, uformowany u schyłku ostatniego zlodowacenia, urozmaicony ciągami wydm Puszczy Kampinoskiej, dlatego jest też określany mianem terasy wydmowej (Kobendzina 1979). Od południa zamyka go wyraźna krawędź, powyżej której, na wysokości około 20 m nad współczesnym korytem Wisły, rozpościera się erozyjna tarasa błońska, wycięty w iłach warwowych zastoiska warszawskiego (Mojski 1967).

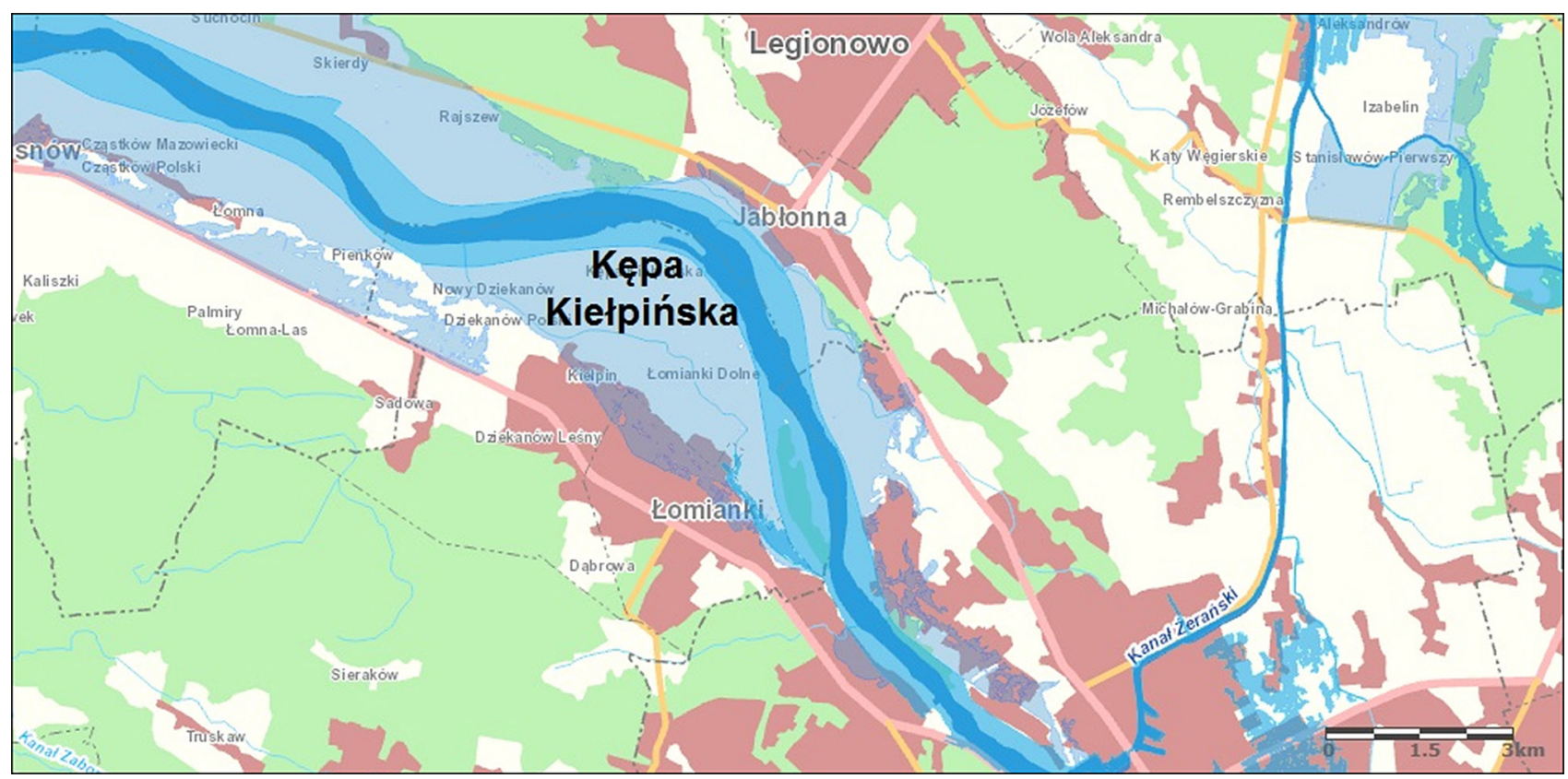

Ryc. 1. Fragment mapy zagrożenia powodziowego (ISOK 2015 - opracowanej w ramach projektu „Informatyczny System Osłony Kraju przed nadzwyczajnymi zagrożeniami” przez Instytut Meteorologii i Gospodarki Wodnej PIB), przedstawiający Kępę Kiełpińską i jej otoczenie; obszary zagrożone poza wałami przeciwpowodziowymi zaznaczono kolorem jasnoniebieskim

Fig. 1. Fragment of the flood risk map (ISOK 2015 - elaborated by Institute of Meteorology and Water Management National Research Institute within the project: „IT system of the country’s protection against extreme hazards”), presenting Kępa Kiełpińska and its surrounding; area at risk outside levees are marked with light blue colour 


\section{Osadnictwo olęderskie w rejonie Warszawy}

Mianem olędrów określa się grupy ludności, zwykle wyznania mennonickiego, które przybywały na teren Polski w wyniku prześladowań religijnych, początkowo z Fryzji i z Flandrii, później także z Niemiec. Przedstawiciele tej społeczności, dzięki wielowiekowej tradycji pozyskiwania nowych terenów nadających się pod uprawę (w tym umiejętności regulacji stosunków wodnych) osiedlali się na wcześniej niewykorzystanych rolniczo obszarach zalewowych lub leśnych (Klassen 2009). Pierwsi z nich przybyli do Polski już w XIII w., jednak główna faza napływu ludności olęderskiej przypadła na wiek XVI i wiązała się z kolonizacją Żuław Wiślanych. Na Mazowsze osadnicy dotarli w XVII w. (w 1628 r. powstała osada na terenie dzisiejszej Saskiej Kępy), ale większość osiedli założono dopiero w połowie wieku XVIII i na początku XIX. Ostatnim z nich była Kępa Zawadowska (założona na podstawie kontraktu z 1832 r.). Łącznie na Mazowszu funkcjonowało w różnych okresach 191 wsi olęderskich, w tym 14 na terenie dzisiejszej Warszawy. Początki osadnictwa i użytkowania rolniczego w obrębie Kępy Kiełpińskiej przypadły najprawdopodobniej na początek XIX w. (Szałygin 2004, 2011). Kolonistów niemieckich z terenów, na których wcześniej upowszechnił się sposób gospodarowania przejęty od osadników olęderskich (dlatego także w stosunku do nich często stosowane jest określenie „olędrzy”), sprowadził na ten teren dziedzic Łomianek Fryderyk (wg innych źródeł Franciszek) Poths. W 1803 r. założyli oni osadę, na którą w okresie świetności, tj. około 100 lat później, składało się 29 gospodarstw

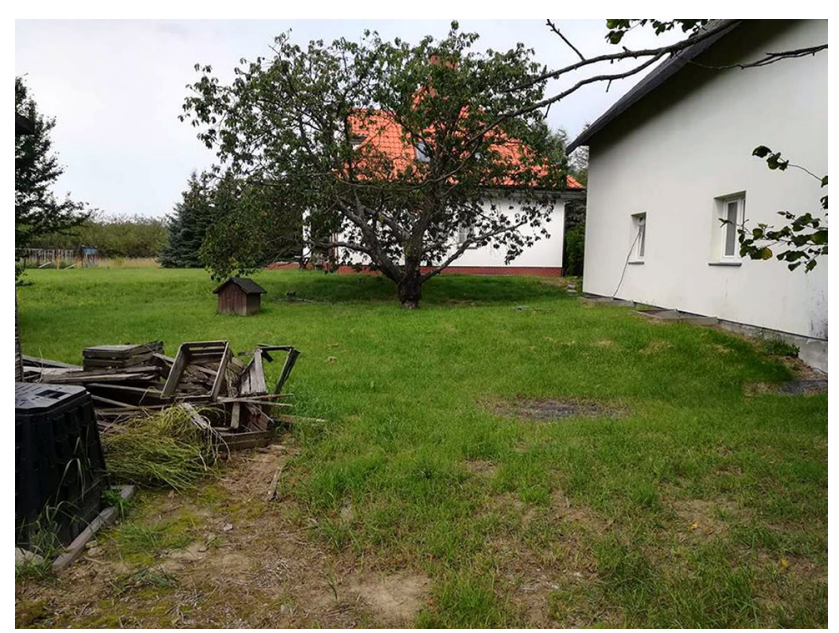

Ryc. 2. Współczesne budynki Kępy Kiełpińskiej posadowione na olęderskich nasypach (terpach) (fot. U. ZawadzkaPawlewska)

Fig. 2. Modern buildings of the Kępa Kiełpińska build on Olęder artificial rises (terpa) (photo U. Zawadzka-Pawlewska)

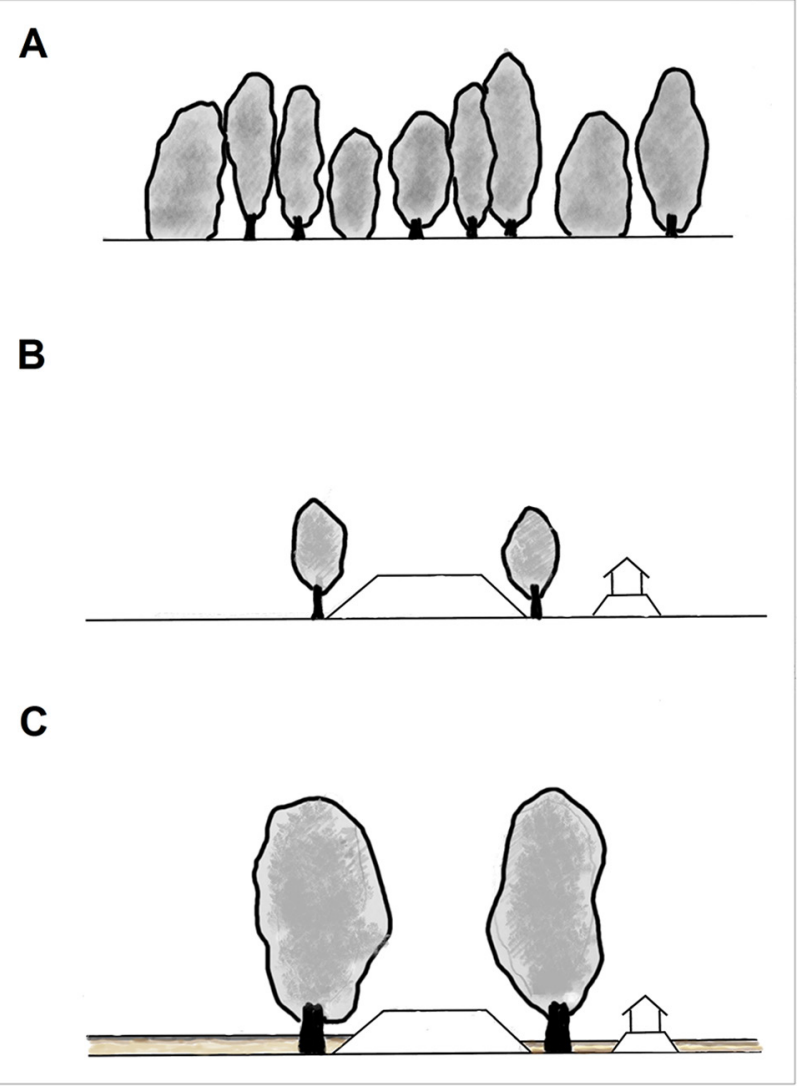

Ryc. 3. Schemat przekształceń krajobrazu Kępy Kiełpińskiej w ciągu ostatnich dwóch stuleci

A - przed 1800 r., B - pierwsza połowa XIX w., C - współcześnie; pozostałe objaśnienia $\mathrm{w}$ tekście.

Fig. 3. Scheme of Kępa Kiełpińska landscape transformations during last two centuries

A - before $1800, B$ - first half of the $19^{\text {th }}$ century, C - today, more explanations in the text.

(Pustoła-Kozłowska, Konopka 2005). Osadnictwo na terasie zalewowej Wisły w bezpośrednim sąsiedztwie rzeki wymagało wycięcia porastającej ten teren roślinności łęgowej i osuszenia podmokłych gruntów. Zgodnie z praktyką wprowadzoną przez osadników olęderskich, dokonano tego poprzez wykonanie odwodnienia oraz usypanie systemu grobli otaczających pola, obsadzonych wierzbami i topolami. Dodatkowo stawiano płotki z gałęzi wierzbowych (ślady plantacji, z których je pozyskiwano, widoczne są do dziś). Ich celem było zatrzymywanie osadów powodziowych, nadbudowujących i użyźniających pola (Szałygin 2004). Zabudowania lokalizowano na nasypach (tzw. terpach - Szałygin 2011, Parat 2012) w pobliżu rzeki, wykorzystując fakt występowania tam odsypu meandrowego zbudowanego z materiału grubszego niż dalej położone fragmenty terasy zalewowej. Na Kępie Kiełpińskiej nie zachowały się budynki z okresu osadnictwa olęderskiego, ale współczesne domy posadowione są również na nasypach (ryc. 2, 3), z których część ma prawdopodobnie założenia dziewiętnastowieczne. 
Skuteczność zabiegów podjętych przez olędrów potwierdza fakt, że choć powódź zatorowa z marca 1924 r. zniszczyła znaczne fragmenty pól Kępy Kiełpińskiej (Kolago 1967), to kolejna powódź opadowa z 1934 r.,
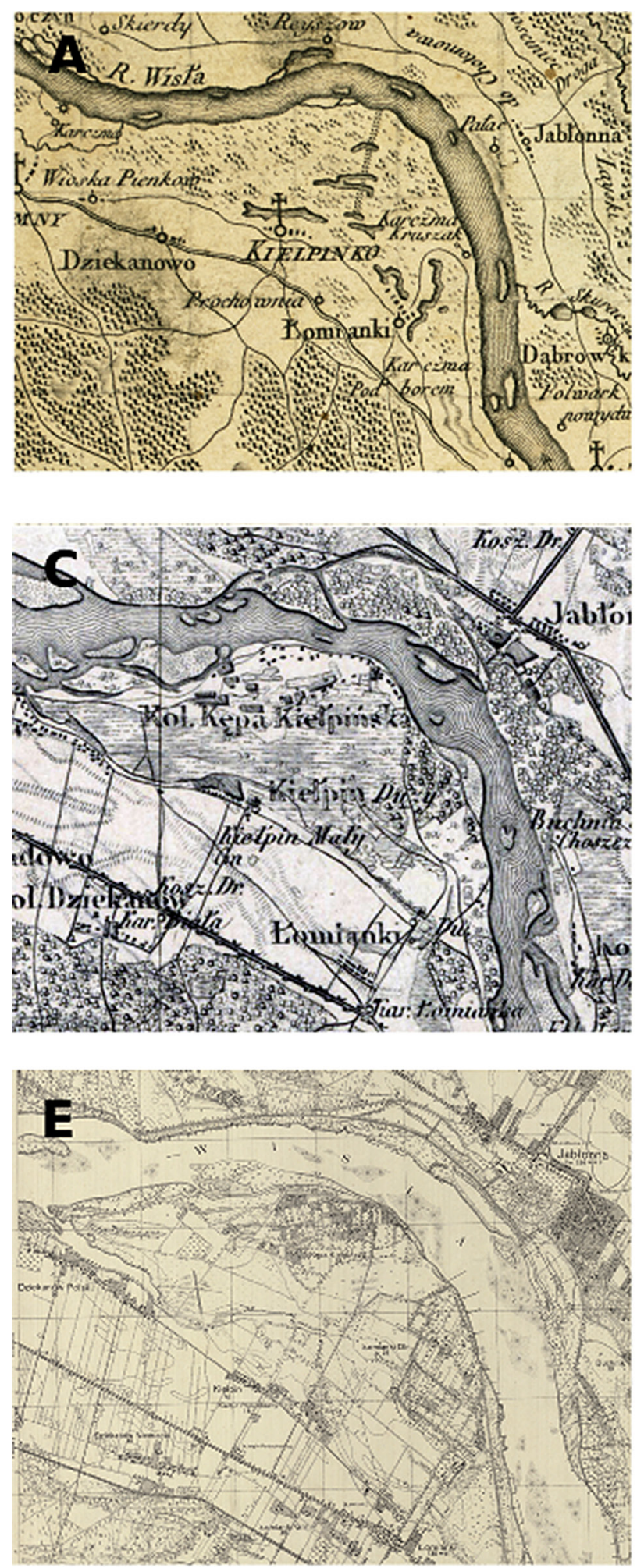

katastrofalna w Warszawie (stan wody w Porcie Praskim o $9 \mathrm{~cm}$ niższy niż podczas powodzi z $1924 \mathrm{r}$. Magnuszewski, Gutry-Korycka 2009), objęła już tylko fragment Kępy (wg mapy WIG 1:500 000 z 1935 r.).
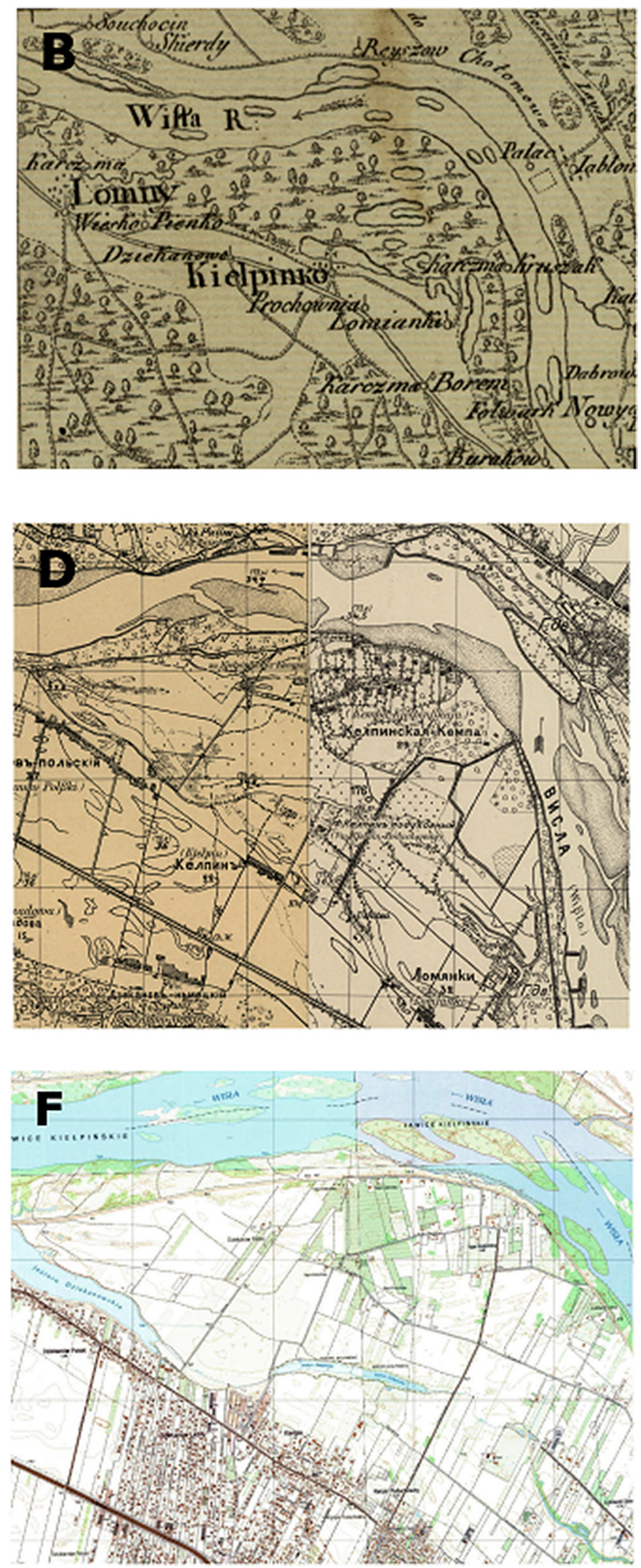

Ryc. 4. Kępa Kiełpińska na mapach z lat: A - 1783, B - 1794, C - 1843, D - 1914 i 1915, E - 1936, F - na mapie współczesnej. Szczegółowe objaśnienia w tekście

Fig. 4. Kępa Kiełpińska on maps from years: A - 1783, B - 1794, C - 1843, D - 1914 and 1915, E - 1936, F - on modern map. Detailed explanations in the text 


\section{Metody badań}

Główny cel opracowania realizowano, stosując zarówno metody kameralne, jak i terenowe. Na podstawie analizy dostępnej literatury prześledzono historię osadnictwa olęderskiego $\mathrm{w}$ analizowanym fragmencie doliny Wisły. Do określenia bezpośrednich skutków antropopresji wykorzystano archiwalne mapy topograficzne $z$ lat:

- 1783 (Karola de Perthéesa, w skali 1:225 000 ryc. $4 \mathrm{~A})$,

- 1794 (Karola de Perthéesa, w skali 1:225 000 ryc. 4B),

- 1843 (ok. roku 1850?) (Topograficzna karta Królestwa Polskiego w skali 1:126 000 - ryc. 4C),

- 1914 i 1915 (niemiecka mapa zaboru rosyjskiego w skali 1:25 000 - ryc. 4D),

- 1936 (Mapa szczegółowa Polski WIG, w skali 1:25 000, wykonana na podstawie rosyjskiego zdjęcia topograficznego $z$ lat 1885-1892 - ryc. 4E) oraz

- współczesną mapę topograficzną w skali 1:10 000 w układzie współrzędnych „1992” - ryc. 4F.

Wymienione mapy pozyskano: z zasobów udostępnianych w systemie Mapster (1783, 1843, 1914), ze zbiorów Biblioteki Uniwersytetu Warszawskiego, za zgodą Gabinetu Zbiorów Kartograficznych BUW (1794), z internetowego Archiwum Map Wojskowego Instytutu Geograficznego 1919-1939 (1936) oraz z zasobów Centralnego Ośrodka Dokumentacji Geodezyjnej i Kartograficznej (współczesna mapa topograficzna).

Na podstawie zgromadzonego materiału kartograficznego i rekonesansu terenowego wybrano punkty, w których wykonano wiercenia służące wskazaniu wpływu osadnictwa na cechy litologiczne podłoża. Zlokalizowano je na skraju płytkiego obniżenia stanowiącego pozostałość po wypełnionym starorzeczu, w odległości około $160 \mathrm{~m}$ od siebie, po dwóch stro-

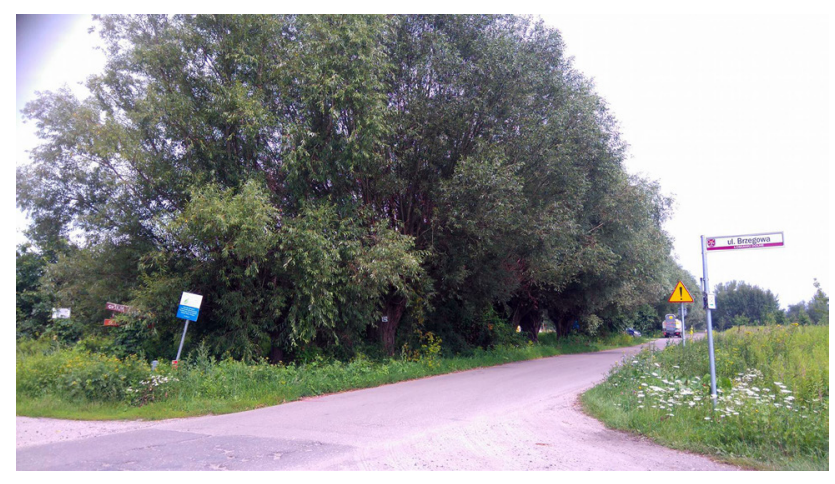

Ryc. 5. Wierzby wzdłuż olęderskiej grobli, którą obecnie prowadzi droga asfaltowa (skrzyżowanie ulic 6 Pułku Piechoty i Brzegowej) (fot. I. Tsermegas)

Fig. 5. Willows along Olęder causeway, on which presently runs an asphalt road (crossroad of the 6 Pułku Piechoty and Brzegowa streets) (photo I. Tsermegas)

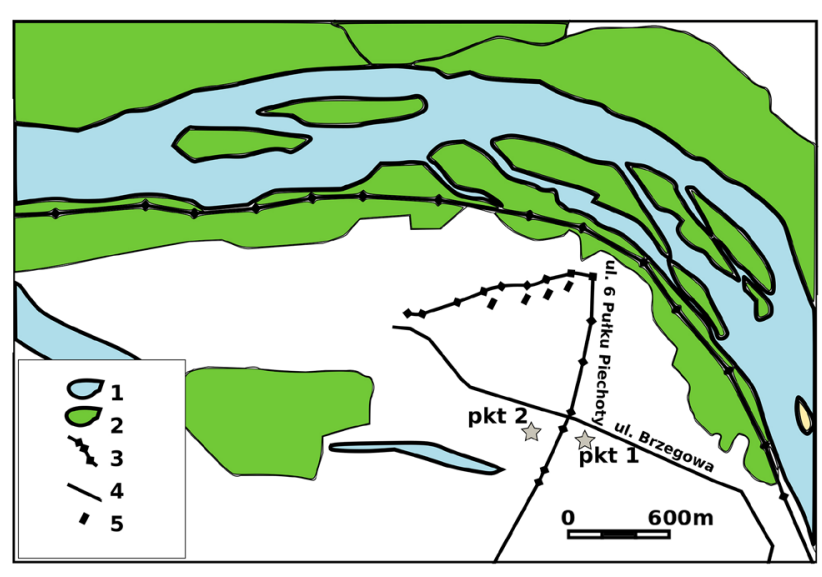

Ryc. 6. Lokalizacja wierceń (nr 1 i 2) na tle wybranych elementów topografii rejonu Kępy Kiełpińskiej

1 - wody powierzchniowe, 2 - zarośla łęgowe, 3 - wały przeciwpowodziowe i groble, 4 - ulice, 5 - zabudowania

Fig. 6. Localisation of drills ( 1 and 2 ) against the background of the selected topography features of the Kępa Kiełpińska area

1 - surface water, 2 - riparian forest, 3 - levees and causeways, 4 - streets, 5 - buildings

nach głównej olęderskiej grobli prostopadłej do koryta Wisły, którą obecnie prowadzi droga asfaltowa (ul. 6 Pułku Piechoty; ryc. 5, 6).

Do porównania podstawowych cech materiału uzyskanego $z$ wierceń wykorzystano klasyczną analizę uziarnienia (wykonaną metodą sitową) oraz analizę zawartości materii organicznej (metodą strat prażenia $\mathrm{w}$ temperaturze $550^{\circ} \mathrm{C}$ ).

\section{Wyniki badań}

$\mathrm{Na}$ podstawie analizy porównawczej map archiwalnych (ryc. 4) stwierdzono, że od początków XIX w. na obszarze Kępy Kiełpińskiej nastąpiły wyraźnie zmiany w sieci hydrograficznej i pokryciu terenu. Pod koniec XVIII w. był to teren podmokły i zalesiony (obecność drzew sugerują mapy z 1783 r. i $1794-$ ryc. 4A i 4B). Wprawdzie mapa z roku 1783 (ryc. 4A) przedstawia odmienną sytuację topograficzną - na obszarze Kępy Kiełpińskiej widoczne są rzadkie zadrzewienia, a prostopadle do rzeki, w miejscu później usypanej głównej grobli, biegnie wyraźny pas drzew, jednak różnicę tę trudno interpretować $\mathrm{w}$ kategoriach zmian morfologicznych. Najprawdopodobniej wspomniany element linijny został z nieznanych powodów pominięty przez redaktora mapy $z$ roku 1794 (ryc. 4B), ale można uznać, że jest to pierwszy na tym terenie ślad zabiegów służących osuszeniu podłoża, podjętych jeszcze przed przybyciem głównej grupy osadników olęderskich.

W pierwszej połowie XIX w. (ryc. 4C) znacznie zmniejszył się udział roślinności drzewiastej, a na 
północy, w osuszonym pasie równoległym do Wisły, powstały zabudowania (i pierwsze terpy, na których je lokalizowano), dostępne przypuszczalnie jedynie ze skrajnych części Kępy, której centrum nadal pozostawało podmokłe, niewykorzystane rolniczo. $\mathrm{Na}$ początku XX w., w okresie I wojny światowej, znaczna część badanego obszaru była już wykorzystana rolniczo (ryc. 4D). Dostęp do pól i zabudowań Kępy Kiełpińskiej zapewniała droga wiodąca z Kiełpina, usytuowana na prostopadłej do Wisły grobli, której kontynuację $\mathrm{w}$ kierunku zachodnim stanowił niski wał przeciwpowodziowy.

Główna grobla łączyła się $z$ wałem przeciwpowodziowym biegnącym od strony Warszawy i oddzielała (a więc chroniła przed zalaniem) tereny Kępy Kiełpińskiej od gruntów Łomianek i wschodniej części Kiełpina. Naturalna sieć odpływu powierzchniowego wód z Kępy, skierowana na zachód, została pogłębiona, a ślady tego pogłębienia widoczne są do dziś $\mathrm{w}$ morfologii równiny $\mathrm{w}$ postaci wyraźnych podłużnych obniżeń. Granice pól wokół zabudowań Kępy były obsadzone drzewami (nadal występuje tam sieć zadrzewień, złożona głównie $z$ wierzb) i prawdopodobnie podwyższone $\mathrm{w}$ stosunku do terenów otaczających. Są dobrze widoczne na mapie z 1914 r. (ryc. 4D). Zatem miedze te pełniły także funkcję grobli, a materiał do ich usypania mógł pochodzić z sąsiadujących z nimi płytkich rowów, które w większości przypadków nie zaznaczają się dziś w rzeźbie, ale ich
A

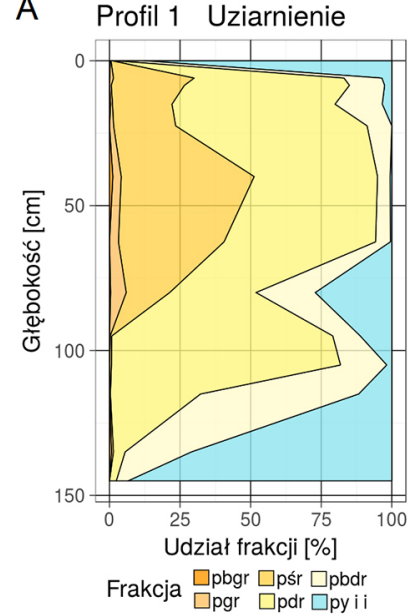

B Materia organiczna

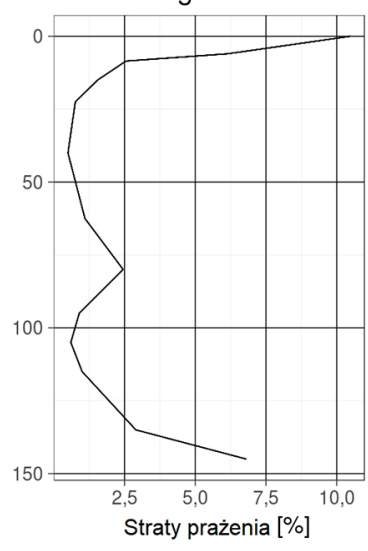

Ryc. 7. Uziarnienie i zawartość materii organicznej w osadach terasy zalewowej przed olęderską groblą - profil pionowy osadów, wiercenie 1

pbgr - piasek bardzo gruboziarnisty, pgr - piasek gruboziarnisty, pśr - piasek średnioziarnisty, pdr - piasek drobnoziarnisty, pbdr - piasek bardzo drobnoziarnisty, py i i - pył i if

Fig. 7. Grain size distribution and LOI in sediments of the floodplain at front of the Olęder causeway - depth profile, drill no. 1

pbgr - very coarse-grained sand, pgr - coarse-grained sand, pśr - middle-grained sand, pdr - fine- grained sand, pbdr - very fine grained sand, py i i - silt and clay ślad mogą stanowić strefy podkreślone obecnością roślinności wilgociolubnej. Na osiedle składało się 29 zabudowań ulokowanych na nasypach mogących wówczas osiągać nawet metr wysokości. Współczesne lewobrzeżne obwałowania na omawianym odcinku doliny usypano dopiero w XX w. (Plit 2008).

Wyniki analiz osadów wskazują, że utworzenie systemu grobli i rowów służyło nie tylko doraźnemu zabezpieczeniu przed skutkami powodzi (w przypadku wylewów o ograniczonym zasięgu), ale mogło też w sposób znaczący wpłynąć na cechy gruntów użytkowanych przez olędrów, bowiem w czasie dużych powodzi groble i pasy zarośli wierzbowo-topolowych oraz płotki $z$ wikliny zatrzymywały grubszy materiał, a drobniejsze frakcje wzbogacone $\mathrm{w}$ materię organiczną, transportowane w zawiesinie, osadzały się w obrębie kolejno zalewanych pól.

Taki model antropogenicznie wymuszonej sedymentacji znajduje potwierdzenie zarówno w zróżnicowaniu składu granulomentycznego, jak i zawartości materii organicznej w profilach badanych osadów (ryc. 7, 8). W obu przypadkach w spągu stwierdzono obecność mady pylastej, w której udział frakcji drobniejszych od piasku przekracza $80 \%$, a zawartość materii organicznej wynosi $6-8 \%$. Jej strop zalega na głębokości $130 \mathrm{~cm}$ (w wierceniu przed groblą; profil $\mathrm{nr}$ 1) i $95 \mathrm{~cm}$ (w wierceniu poniżej grobli - zgodnie z biegiem Wisły; profil nr 2). Należy przypuszczać, że poziom ten jest zapisem sprzed momentu zmiany
A

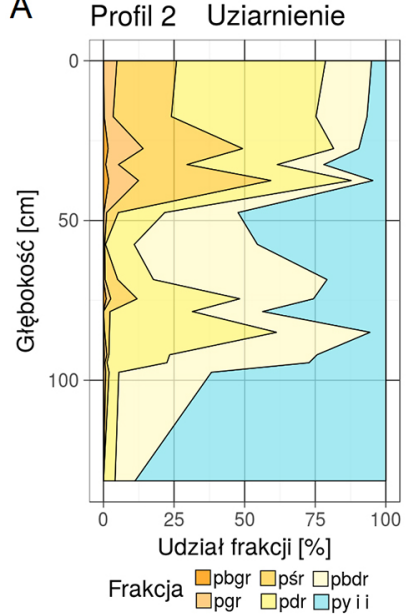

B Materia organiczna

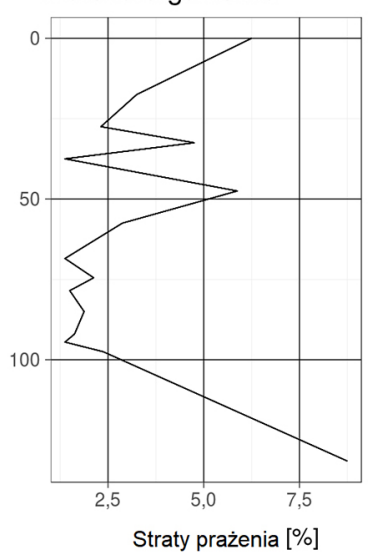

Ryc. 8. Uziarnienie i zawartość materii organicznej w osadach terasy zalewowej za olęderską groblą - profil pionowy osadów, wiercenie 2

pbgr - piasek bardzo gruboziarnisty, pgr - piasek gruboziarnisty, pśr - piasek średnioziarnisty, pdr - piasek drobnoziarnisty, pbdr - piasek bardzo drobnoziarnisty, py i i - pył i if

Fig. 8. Grain size distribution and LOI in sediments of the floodplain behind the Olęder causeway - from depth profile, drill no. 2

pbgr - very coarse-grained sand, pgr - coarse-grained sand, pśr - middle-grained sand, pdr - fine- grained sand, pbdr - very fine grained sand, py i i - silt and clay 
warunków sedymentacji z naturalnych na uwarunkowane obecnością grobli. Leżące powyżej niego osady obu profili znacznie się od siebie różnią.

W profilu nr 1 nieznacznie wzbogacony w drobne frakcje (nieco ponad $25 \%$ pyłu wraz z iłem) jest poziom na głębokości $75-85 \mathrm{~cm}$, w którym zaznacza się też wzrost zawartości materii organicznej (do $2,5 \%$ ). Powyżej i poniżej dominują utwory piaszczyste, głównie piaski drobnoziarniste, $w$ górnej części profilu ze znacznym udziałem piasków średnioziarnistych. Zawartość materii organicznej nie przekracza $1-1,5 \%$. Jedynie $\mathrm{w}$ warstwie powierzchniowej $(0-5$ $\mathrm{cm}$ ) udział piasku nie przekracza $15 \%$, reszta to materiał drobniejszy. Materia organiczna stanowi około $10 \%$ masy osadu.

W profilu nr 2 wyraźnie dominują osady facji powodziowych - istotny udział pyłu i iłu (od 20 do nawet $50 \%$ ) odnotowano na głębokości $45-80 \mathrm{~cm}$. W górnej części tego poziomu znacząco wzrasta też (do ponad 6\%) zawartość materii organicznej. Powyżej występują głównie piaski (przede wszystkim średnio- i drobnoziarniste, podczas gdy głębiej frakcją podstawową były piaski bardzo drobnoziarniste), w warstwie 35-40 cm stanowią blisko $100 \%$ masy osadu, a udział materii organicznej spada niemal do zera, po czym na głębokości $30 \mathrm{~cm}$ wzrasta do powyżej $4,5 \%$. Ponad tym poziomem przeważają piaski drobnoziarniste, zawartość substancji organicznych wzrasta ku powierzchni z niespełna $2,5 \%$ do ponad $6 \%$.

\section{Wnioski}

Badania wykazały, że osadnictwo olęderskie w rejonie Kępy Kiełpińskiej w sposób znaczący wpłynęło na morfologię tego obszaru. W pierwszej fazie modyfikacja rzeźby miała głównie charakter bezpośredni i polegała na utworzeniu nowych form - grobli, rowów, nasypów. Szczegółowa ilościowa analiza tych zmian będzie możliwa po uzyskaniu danych z cyfrowych modeli wysokościowych wykonanych techniką LiDAR na potrzeby programu ISOK, ale z już wykonanej analizy map archiwalnych wynika, że skala wspomnianych przekształceń jest duża. Potwierdza to również fakt, że ich skutki są do dziś wyraźnie widoczne $\mathrm{w}$ terenie.

Następstwem zmian bezpośrednich była modyfikacja przebiegu naturalnych procesów kształtujących rzeźbę i osady równiny zalewowej. Przed wybudowaniem wałów przeciwpowodziowych w trakcie wylewów Wisły niesione przez nią osady piaszczyste były przynajmniej częściowo zatrzymywane przez system olęderskich grobli, płotków z wikliny i pasów zadrzewień, dzięki czemu na powierzchni pól za tymi sztucznymi przeszkodami akumulowane były głów- nie osady drobniejsze, z dużym udziałem pyłu i iłu, co wpływało też na poprawę żyzności gleb. Znaczne ilości piasku dosypywane były na powierzchnie wykorzystywane pod uprawę jedynie w czasie największych powodzi. Poziomy wyraźnie piaszczyste widoczne w górnej części profilu nr 2 mogły powstać podczas katastrofalnej powodzi w 1924 r., po której fragment Kępy Kiełpińskiej, na którym wykonano wiercenia, nie był już prawdopodobnie zalewany. Zatem uzyskane wyniki dowodzą, że rzeźba dna doliny Wisły w rejonie Kępy Kiełpińskiej podlega silnej antropopresji od co najmniej 200 lat, i zachęcają do podejmowania dalszych badań zmierzających przede wszystkim w kierunku ilościowej oceny zmian, które nastąpiły po zasiedleniu tego obszaru przez kolonistów olęderskich.

\section{Literatura}

De Perthées K., 1794. Okolica Warszawy w Diametrze Piąciu Mil. Mapa szczegulna województwa mazowieckiego w skali 1:222 500 wyrytowana w Paryżu przez P.F. Tardieu [z kolekcji Gabinetu Zbiorów Kartograficznych Biblioteki Uniwersytetu Warszawskiego].

De Perthées K., Serrurier L., 1783. Okolica Warszawy w Diametrze Piąciu Mil. Szczegółowe mapy województw 1:222 500 [ze zbiorów Archiwum Głównego Akt Dawnych w Warszawie; dostępna w systemie MAPSTER: Perthees-Okol_W-wy_w_diam_5mil_1783@AGAD-Zb._Kart._69-22B_(Zb._SA_118).jpg].

Doroszewski W. (red.), 196̄̄. Słownik języka polskiego. T. III. Wiedza Powszechna, Warszawa.

Forysiak J., 2005. Funkcjonowanie i zanik wielokorytowego układu rzecznego Warty, Neru i Grabi (dorzecze środkowej Warty) w neoholocenie. W: A. Kotarba, K. Krzemień, J. Święchowicz (red.), VII Zjazd Geomorfologów Polskich. Współczesna ewolucja rzeźby Polski. IGiGP UJ, Kraków: 121-124.

Forysiak J., Kulesza M., Twardy J., 2007. Wpływ osadnictwa olęderskiego na sieć rzeczną i morfologię międzyrzecza Warty i Neru. W: E. Smolska, P. Szwarczewski (red.), Zapis działalności człowieka w środowisku przyrodniczym. T. III. Wyd. SWPR, Warszawa: 39-45.

Klassen P.J., 2009. Mennonites in early modern Poland and Prussia. The John Hopkins University Press, Baltimore.

Kobendzina J., 1979. Zagadnienia przyszłości Puszczy Kampinoskiej. W: S. Leszczycki, J. Kobendzina (red.), Kampinoski Park Narodowy i jego problematyka. Dokumentacja Geograficzna IGiPZ PAN 1: 16-28.

Kobojek E., Kobojek S., 2013. Środowisko przyrodnicze i problemy zagospodarowania pradolin. Studia KPZK 152: 358-369.

Kolago C., 1967. Od ujścia Wilanówki do ujścia Narwi. W: C. Kolago (red.), Z biegiem Wisły. Przewodnik geologiczno-krajoznawczy. Wydawnictwa Geologiczne, Warszawa: 311-348.

Magnuszewski A., Gutry-Korycka M., 2009. Rekonstrukcja przepływu wielkich wód Wisły w Warszawie w warunkach naturalnych. Prace i Studia Geograficzne 43: 141-151.

Mapa Szczegółowa Polski w skali 1:25 000, 1936. Arkusz Jabłonna, pas 39, słup 32-D (zdjęcie topograficzne rosyjskie z lat 1885-1892). Wojskowy Instytut Geograficzny, Warszawa [ze zbiorów Biblioteki Kongresu Stanów Zjednoczonych w Waszyngtonie; dostępna w systemie MAPSTER: P39-S32-D_JABLONNA_1936_LoC_G6520_s25_.P6.jpg].

Mapa topograficzna Polski w skali 1:10 000, układ 1992, arkusze: Rajszew (N-34-126-D-c-2), Łomna (N-34-126-D-c-4), Legionowo (N-34-126-D-d-1), Łomianki (N-34-126-D-d-3) [z zasobów 
Centralnego Ośrodka Dokumentacji Geodezyjnej i Kartograficznej w Warszawie].

Mojski J.E., 1967. Od ujścia Narwi do Dobrzykowa. W: C. Kolago (red.), Z biegiem Wisły. Przewodnik geologiczno-krajoznawczy. Wydawnictwa Geologiczne, Warszawa: 348-370.

Myga-Piątek U., 2012. Krajobrazy kulturowe. Aspekty ewolucyjne i typologiczne. Uniwersytet Śląski, Katowice.

Niemiecka mapa zaboru rosyjskiego w skali 1:25 000, 1914. Arkusz Nowogeorgijewssk-Segrshe-Warschau, Bl. 26, XXII 9-Г [ze zbiorów Biblioteki Wydziału Geografii i Studiów Regionalnych Uniwersytetu Warszawskiego; dostępna w systemie MAPSTER: XXII-9-D_Nowogeorgijewssk-Segrshe-Warschau_Bl_26_1914 UWar.jpg].

Niemiecka mapa zaboru rosyjskiego w skali 1:25 000, 1915. Arkusz Nowogeorgijewssk-Segrshe-Warschau, Bl. 25, XXII 8-E [ze zbiorów Biblioteki Wydziału Geografii i Studiów Regionalnych Uniwersytetu Warszawskiego; dostępna w systemie MAPSTER: http://maps.mapywig.org/m/German_maps/series/025K_Westl_Russland/XXII-8-F_Nowogeorgijewssk-Segrshe-Warschau_ Bl_25_Feldstellungen_1915.jpg].

Plit $\bar{J}$., 2008 . Zarządzañie krajobrazem dolin rzecznych. W: U. Myga-Piętek, K. Pawłowska (red.), Zarządzanie krajobrazem kulturowym. Prace Komisji Krajobrazu Kulturowego PTG 10: 230-240.

Plit J., 2010. Naturalne i antropogeniczne przemiany krajobrazów delty Wisły. W: J. Plit (red.), Krajobrazy kulturowe dolin rzecz- nych. Potencjał i wykorzystanie. Prace Komisji Krajobrazu Kulturowego PTG 13: 13-28.

Plit J., 2016. Krajobrazy kulturowe Polski i ich przemiany. Prace Geograficzne IGiPZ PAN 253.

Prarat M., 2012. Architektura chłopska doliny dolnej Wisły w latach 1772-1945 i jej problematyka konserwatorska. Muzeum Etnograficzne im. Marii Znamierowskiej-Prüfferowej, Toruń.

Pustoła-Kozłowska E., Konopka M., 2005. Dawne Łomianki. Historia, ludzie, zabytki. Wydawnictwo Drograf, Łomianki.

Sarnacka Z., 1980. Objaśnienia do szczegółowej mapy geologicznej Polski 1:50 000. Arkusz Warszawa Wschód (524). Wydawnictwa Geologiczne, Warszawa.

Starkel L., 2001. Historia doliny Wisły od ostatniego zlodowacenia do dziś. Monografie IGiPZ PAN 2.

Szałygin J., 2004. Katalog zabytków osadnictwa holenderskiego na Mazowszu. Wydawnictwo DiG, Warszawa.

Szałygin J., 2011. Dziedzictwo kultury olęderskiej na Mazowszu. Mazowsze. Studia Regionalne 7: 125-137. Online: www.mazowszestudiaregionalne.pl/user_uploads/image/PRAWE\%20 MENU/NUMERY\%20ARCHIWĀLNE/07/msr_7_szalygin.pdf -24.08 .2017 .

Topograficzna karta Królestwa Polskiego w skali 1:126 000, 1843. Arkusz Warszawa, kolumna IV, sekcja III [ze zbiorów Archiwum Map WIG; dostępna w systemie MAPSTER: MTKP_126K_Kol_ IV_Sek_III.jpg]. 